\title{
Sero-Prevalence of Rubella Virus among Pregnant Women in Kaduna State Nigeria 2015
}

\author{
Aishatu B. Gubio*, Steve Olonitola, Edward Jattau and Maryam A. Mukhtar \\ Ahmadu Bello University, Zaria, Nigeria
}

\section{Objective}

To determine the IgM and IgG antibodies of rubella virus circulating among pregnant women in Kaduna State Nigeria.

\section{Introduction}

Rubella virus causes -“German measles," also known as "three-day measles." This is usually a milder disease than red measles. Red/Hard measles or just measles is caused by Rubeola virus. The result of acute infection of the virus is a benign systematic rash which is significantly pathogenic to humans. This virus is a, positive-strand RNA virus that replicates in the cytoplasm of the infected cell. (Brooks et al., 2007). If placental infection of the virus spread during 8-10 weeks gestation it causes a chronic infection of the fetus leading to the development of congenital rubella syndrome (CRS) (Matthews et al., 2011) The effect of the infection of the several organ systems which include the eyes, ears, heart, brain, and endocrine system is known as congenital rubella infection (CRI) (Chantler $e t$, al.,2001)

Rubella is endemic in Nigeria. Studies among women of child bearing age in Nigeria put seroprevalence at $66.6 \%$ in Imo, $77 \%$ in Lagos and $93.5 \%$ in Oyo (8-10). Thus as part of the control measure, the availability of an effective vaccine to prevent Rubella infection and therefore CRS, is necessary to evaluate the burden of disease in a country where MMR vaccine is not covered in the immunization schedule or in vaccination strategy

\section{Methods}

A cross-sectional study carried out on pregnant women attending ante-natal clinic from the three different senatorial district in Kaduna state. Blood samples were screened for rubella IgM \& IgG antibody using commercially produced enzyme linked immunosorbent assay (ELISA), Questionnaires were administered to obtain demographic information and possible risk factors associated with rubella virus. Data was analzyed using Epi Info 6 Version 3.5.3.

\section{Results}

Of the 900 pregnant women screened, 572(63.3\%) were positive for rubella IgG. The prevalence of rubella IgG was highest among the age group 21-25 with $198(34.6 \%)$ and IgM was highest among the age group 21-25(51.3\%). The IgG test results shows that $317(66.0 \%)$ pregnant women tested positive for their first trimester, while the IgM positive results shows $17(33.3 \%)$ for their first trimester. Although the southern senatorial district had the highest seroprevalence $14(35.9 \%)$ among the three centres, the differences were not statistically significant $(p>0.05)$. Only 3 people claimed to have been vaccinated against rubella virus. Acquisition of primary education and being a house wife were insignificantly associated with raised titres. ( $p>0.05)$.

\section{Conclusions}

The serological evidence of rubella virus found in pregnant women among age group \& their first trimester in this study is an indication that rubella is prevalent in Nigeria. It is however still necessary to immunize seronegative women against rubella before they get pregnant.
Table 1: Sero-prevalence of Rubella Antibodies Among Pregnant Women Attending Antenatal clinic in Kaduna State Based on Age

\begin{tabular}{|c|c|c|c|}
\hline $\begin{array}{c}\text { Age grp } \\
\text { (Yrs) }\end{array}$ & No. Screened & $\begin{array}{c}\text { IgG } \\
\text { Positive }(\%)\end{array}$ & $\begin{array}{c}\operatorname{IgM} \\
\text { Positive }(\%)\end{array}$ \\
\hline $11-15$ & 8 & $5(62.5)$ & $0(0)$ \\
\hline $16-20$ & 160 & $99(61.5)$ & $7(4.4)$ \\
\hline $21-25$ & 328 & $198(60.4)$ & $20(6.1)$ \\
\hline $26-30$ & 224 & $155(69.2)$ & $7(3.1)$ \\
\hline $31-35$ & 132 & $82(62.1)$ & $3(2.3)$ \\
\hline $36-40$ & 41 & $28(68.3)$ & $2(4.9)$ \\
\hline $41-45$ & 6 & $5(83.3)$ & $0(0)$ \\
\hline Greater Than 45 & 1 & $0(0)$ & $0(0)$ \\
\hline Total & 900 & $572(63.5)$ & $39(4.3)$ \\
\hline
\end{tabular}

Table 2: Sero-prevalence of Rubella Antibodies among Pregnant Women Attending Ante-Natal Clinic in Kaduna State Based on Trimesters

\begin{tabular}{|c|c|c|c|c|}
\hline Trimesters & Senatorial District & No. Screened & No. IgG Positive $\%$ & No. IgM Positive $\%$ \\
\hline First & SSD* $^{*}$ & 183 & $96(52.5)$ & $7(3.8)$ \\
\hline Second & & 87 & $71(81.6)$ & $5(5.7)$ \\
\hline Third & & 30 & $40(133.3)$ & $2(6.7)$ \\
\hline First & NSD* $^{*}$ & 168 & $85(50.6)$ & $8(4.8)$ \\
\hline Second & & 73 & $66(90.4)$ & $3(4.1)$ \\
\hline Third & & 59 & $47(79.7)$ & $2(3.4)$ \\
\hline First & CSD* $^{*}$ & 146 & $92(6.2)$ & $9(6.2)$ \\
\hline Second & & 88 & $62(70.5)$ & $9(6.2)$ \\
\hline Third & & 66 & $13(19.7)$ & $3(3.4)$ \\
\hline Total & & 900 & $572(63.6)$ & $39(43.3)$ \\
\hline
\end{tabular}

SSD-Southern Senatorial District,

NSD-Northern Senatorial District,

CSD-Central Senatorial District.

Figure 1: Prevalence of Rubella-Virus-Specific Immunoglobulin G and M Among Pregnant Women Attending ANC in the Three Sen atorial Districts of Kaduna State

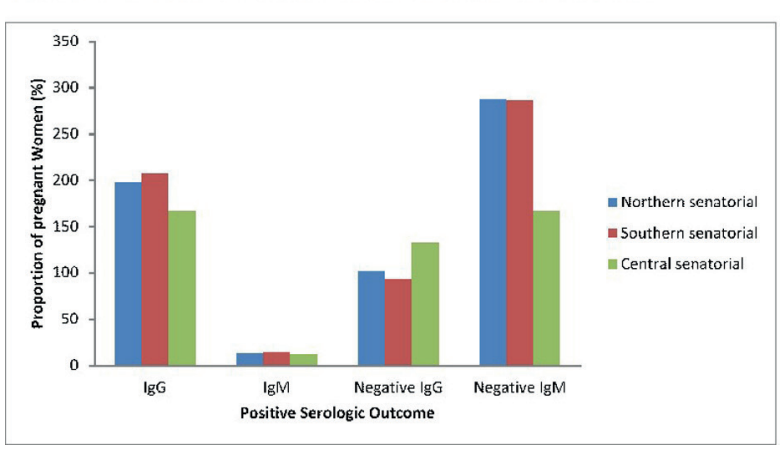

Keywords

Rubella; IgG; IgM

\section{Acknowledgments}

I would like to acknowledge and express my sincere gratitudes to Prof O.S Olonitola, Prof E.D. Jattau, and Dr. M. Aminu- Mukhtar who mentored me. For their immense contributions I simply say thank you. 
References

Brooks, F. G., Carroll, C. K., Butel, S. J. and Morse, A. S. (2007). Jawetz, Melnick, \& Adelberg's Medical Microbiology. $24^{\text {th }}$ ed. U.S.A.: McGraw-Hill Companies. Pp 562-564.

Bukbuk, D. N., El Nafaty A.U. and Obed, J.Y. (2002). Prevalence of Rubella - Specific IgG Antibody in Non - Immunised Pregnant Women in Maiduguri, North-Eastern Nigeria. Central Europe Journal Public Health, 10(1-2): 21 - 23.

Eleazu, C. O., Chinedum, E. K., John, A. Esther, A. (2012). "Survey of the Sero-Prevalence of IgM Antibodies in Pregnant Women Infected With Rubella Virus Plateau State Specialist Hospital in Jos" E3. Journal of Biotechnology and Pharmaceutical Research 3 (1): 10-14.

\section{*Aishatu B. Gubio}

E-mail: yabintu@gmail.com 